\title{
The Impact of Minimum Wage on Urban Residents' Employment
}

\author{
Dongfang Zhang* \\ School of Economics and Management, Beijing Jiaotong University, Beijing, China \\ 16120538@bjtu.edu.cn \\ *Corresponding author
}

Keywords: Minimum wage, Employment, Informal employment

\begin{abstract}
Minimum wage system is a government choice which intends to guarantee low income worker's income and protect their rights and interests. Its impact on employment has led to extensive controversy. Targeted at the urban informal employment, this paper collects panel data of 30 provinces from 2000 to 2010 and studies the impact of minimum wage system on urban employment in China with FGLS. The result of empirical studies shows that a $1 \%$ increase in the minimum wage led to a roughly $0.23 \%$ decrease in urban informal employment. And the sensitivity analysis and dynamic regression extended the range of elasticity to $-0.1 \sim-0.29$. Thus, the government should properly consider the negative impact on employment while adjusting the minimum wage system.
\end{abstract}

\section{Introduction}

The minimum wage system is one of the important means by which all governments control the labor market. By setting a minimum wage, the government can provide basic living guarantees to laborers and their families. In labor economics, researches on the minimum wage have formed a very important part of the discipline. Judging from the current situation in China, the employment situation is already grim. Studying the relationship between changes in minimum wages and employment can provide reference for the formulation of relevant policies. However, there is no consensus on academic research on the minimum wage system. Some scholars think it will further aggravate the employment situation, and weaken the labor cost advantage and affect the competitiveness of enterprises. However, some scholars believe that the minimum wage system is beneficial to protecting the rights and interests of laborers and is conducive to the conversion and upgrading of industrial structure. This paper uses the panel data of 30 provinces in our country from 2000 to 2010 as the research object to investigate the employment of the informal workers who are most sensitive to the minimum wage, and analyzes the impact of the minimum wage on the employment of urban residents in our country.

\section{Organization of the text}

Section 3, according to the invariant substitution elastic production function, the basic measurement model is constructed. Then, the first step is to adopt a gradual regression approach to fully examine the impact of the minimum wage on employment. Then the sensitivity analysis of the optimal model to test the robustness of the conclusions. Finally, we make dynamic estimation at the consideration of the problem of explaining the variables' endogeneity and missing variables. Section 4 summarizes the estimation results of the model, and concludes the relevant policy recommendations. 


\section{Empirical analysis}

\subsection{Model setting}

According to the invariable substitution function of elastic production, an inverse function of labor demand is established, that is, equilibrium employment is decided by labor demand and supply, and the following basic measurement model is established:

$$
Y_{i t}=\alpha_{i t}+\beta_{1} M W_{i t}+\beta_{2} G D P_{i t}+\beta_{3} C P I_{i t}+\beta_{4} U M E M P_{i t}+\beta_{5} P O P_{i t}+\varepsilon_{i t}
$$

\subsection{Descriptive statistics of variables}

Table 1 provides a descriptive statistics of the distribution of the key variables used in the 2000-2010 sample. From Table 1, we can intuitively see that there has been a significant increase in the minimum wage after 2000 .

Table 1: Descriptive statistics of variables

\begin{tabular}{|c|c|c|c|c|c|}
\hline $\begin{array}{c}\text { Variable } \\
\text { name }\end{array}$ & Variable definitions (\%) & Mean & $\begin{array}{c}\text { Standard } \\
\text { deviation }\end{array}$ & Minimum & Maximum \\
\hline (EMP) & $\begin{array}{c}\text { Employment of non-regular workers as a percentage of } \\
\text { total employment of urban units }\end{array}$ & 3.08 & 2.2 & 0.77 & 12.33 \\
\hline (MW) & $\begin{array}{c}\text { The ratio of weighted minimum wage to social average } \\
\text { wage }\end{array}$ & 28.81 & 5.64 & 15.23 & 51.68 \\
\hline (GDP) & GDP growth index & 11.92 & 2.39 & 5.4 & 23.83 \\
\hline (UNEMP) & Urban registered unemployment rate & 3.71 & 0.7 & 0.8 & 6.5 \\
\hline (CPI) & Consumer Price Index & 2.09 & 2.35 & -3.3 & 10.09 \\
\hline (POP) & $\begin{array}{c}16 \text {-year-old to 64-year-old population of the total social } \\
\text { ratio of the population }\end{array}$ & 72 & 4 & 63 & 83 \\
\hline
\end{tabular}

Data sources: according to China Labor Statistical Yearbook and China Statistical Yearbook

\subsection{Model estimation}

\subsubsection{Basic model estimation}

The regression of this paper is based on two-step FGLS estimation.

Table 2: Estimated minimum model of employment impact on employment (FGLS)

\begin{tabular}{|c|c|c|c|c|c|c|}
\hline & Model 1 & Model 2 & Model 3 & Model 4 & Model 5 & Model 6 \\
\hline Explanatory variables & $\begin{array}{c}\text { Only } \\
\text { include } \\
\text { minimum } \\
\text { wage } \\
\text { variable }\end{array}$ & $\begin{array}{l}\text { Add macro } \\
\text { control } \\
\text { variables }\end{array}$ & $\begin{array}{l}\text { Add labor } \\
\text { supply } \\
\text { variables }\end{array}$ & $\begin{array}{c}\text { Control the } \\
\text { fixed effects of } \\
\text { the province }\end{array}$ & $\begin{array}{c}\text { Control the } \\
\text { annual } \\
\text { effect }\end{array}$ & $\begin{array}{c}\text { Add the } \\
\text { minimum } \\
\text { wage dummy }\end{array}$ \\
\hline MW & $\begin{array}{c}-0.028 \\
(0.006)^{* * * *} \\
\end{array}$ & $\begin{array}{c}-0.028 \\
(0.006)^{* * *} \\
\end{array}$ & $\begin{array}{c}-0.029 \\
(0.006) * * * \\
\end{array}$ & $\begin{array}{c}-0.024 \\
(0.005)^{* * *} \\
\end{array}$ & $\begin{array}{c}-0.009 \\
(-0.007)\end{array}$ & $\begin{array}{c}-0.02 \\
(0.005)^{* * *}\end{array}$ \\
\hline GDP & - & $\begin{array}{c}0.012 \\
(-0.011) \\
\end{array}$ & $\begin{array}{c}0.001 \\
(-0.012) \\
\end{array}$ & $\begin{array}{c}0.033 \\
(0.010)^{* * *} \\
\end{array}$ & $\begin{array}{c}0.006 \\
(-0.013) \\
\end{array}$ & $\begin{array}{c}0.025 \\
(0.011)^{* *} \\
\end{array}$ \\
\hline UNEMP & - & $\begin{array}{c}0.216 \\
(0.054)^{* * *} \\
\end{array}$ & $\begin{array}{c}0.154 \\
(0.048)^{* * *} \\
\end{array}$ & $\begin{array}{c}0.178 \\
(0.043)^{* * *} \\
\end{array}$ & $\begin{array}{c}0.055 \\
(-0.046)\end{array}$ & $\begin{array}{c}0.145 \\
(0.040)^{* * * *}\end{array}$ \\
\hline CPI & - & $\begin{array}{c}0.001 \\
(-0.006) \\
\end{array}$ & $\begin{array}{c}0.002 \\
(-0.007)\end{array}$ & $\begin{array}{c}0.005 \\
(-0.006) \\
\end{array}$ & $\begin{array}{c}0.018 \\
(-0.013)\end{array}$ & $\begin{array}{c}0.002 \\
(-0.006)\end{array}$ \\
\hline Labor supply & - & - & $\begin{array}{c}4.426 \\
(1.221)^{* * *} \\
\end{array}$ & $\begin{array}{c}3.085 \\
(1.041)^{* * *} \\
\end{array}$ & $\begin{array}{c}-1.261 \\
(-1.382) \\
\end{array}$ & $\begin{array}{c}2.196 \\
(1.093)^{* *}\end{array}$ \\
\hline The minimum wage dummy & - & - & - & - & - & $\begin{array}{c}0.135 \\
(0.054)^{* *} \\
\end{array}$ \\
\hline Constant term & $\begin{array}{c}3.466 \\
(0.191)^{* * * *} \\
\end{array}$ & $\begin{array}{c}2.467 \\
(0.329)^{* * *} \\
\end{array}$ & $\begin{array}{c}-0.29 \\
(-0.849) \\
\end{array}$ & $\begin{array}{c}4.556 \\
(1.216)^{* * *} \\
\end{array}$ & $\begin{array}{c}7.818 \\
(1.322)^{* * *} \\
\end{array}$ & $\begin{array}{c}5.296 \\
(1.161)^{* * *} \\
\end{array}$ \\
\hline Provincial dummy variables & NO & NO & NO & YES & YES & YES \\
\hline
\end{tabular}


Table 2 continued

\begin{tabular}{|c|c|c|c|c|c|c|}
\hline Annual dummy variable & NO & NO & NO & NO & YES & NO \\
\hline Time trend & NO & NO & NO & NO & NO & NO \\
\hline Minimum wage flexibility & -0.2971 & -0.32067 & -0.22534 & -0.22534 & -0.08293 & -0.18857 \\
\hline Sample size & 330 & 330 & 330 & 330 & 330 & 330 \\
\hline
\end{tabular}

Data sources: according to China Labor Statistical Yearbook and China Statistical Yearbook

Note: The numbers in parentheses in the table are all standard errors. *,**, *** represent significant at the levels of $10 \%$, $5 \%$ and $1 \%$ respectively. The elasticity of the minimum wage is calculated on the sample mean.

Model 1 only includes an explanatory variable of the minimum wage. We can find that there is a significant negative correlation between the minimum wage and employment.

Model 2 has added three macro-control variables that reflect the demand for labor such as GDP, UNEMP and CPI. As the results, the relationship between the minimum wage and the employment is still negative and passes a $1 \%$ significant. After adding three macro-control variables, the absolute value of the elasticity of the minimum wage increases slightly. The coefficients of GDP and CPI are positive, but does not pass the significance test, while the coefficient of registered urban unemployment rate is significantly positive, which means that the employment of urban units in our country shows typical duality characteristics.

Model 3 adds variables reflecting labor supply. It can be seen from the third column of Table 2 that when the equation includes labor supply variables, the regression results are similar to Model 2 , and the labor supply variables themselves are very significant with positive sign, which is also consistent with the theoretical expectation. And the minimum wage and employment still shows a significant negative correlation, but the elasticity decreased from -0.32 to -0.23 .

Model 4 continues to add provincial dummy variables. As can be seen from the results in column 4 of Table 2, the results of the regression are more satisfactory. In the first two models, the GDP does not pass a significant test, but after the provincial dummy variables are added, this variable is significant at the level of $1 \%$ and its coefficient is also greatly increased. The employment of regular workers has a significant pulling effect. Like the previous results, the CPI has not changed its sign or significance. The minimum wage variable is still significantly negative and has the same elasticity as Model 3.

Column 5 of Table 2 reports the results of the regression with further additions to the annual dummy variable. The results of the regression have changed significantly since the control of the annual effects compared to the results of column 4 of Table 2 . The negative relationship between the minimum wage and the employment of informal workers has become insignificant and its flexibility has been greatly reduced. As can be seen from the results of the basic regression in Table 2, irrespective of whether the model includes annual effects, there is a negative correlation between the minimum wage and the employment of informal workers in China. After controlling for macro-control variables, labor supply variables and provincial fixed effects, the negative impact of minimum wages on employment is significant with an elasticity of around -0.23 . That is, when the minimum wage increases by $10 \%$ with respect to the average wage, the proportion of non-official employment in total urban employment in China drops by about $2.3 \%$, which is in line with the majority of the international estimates of the impact of minimum wage employment.

\subsubsection{Sensitivity analysis}

Based on the model 4 in the basic estimation, we conduct various sensitivity analyzes on the basis regressions to test the robustness of the conclusions (see Table 3). 
Table 3: Various sensitivities of minimum wage to employment impact (FGLS)

\begin{tabular}{|c|c|c|c|c|}
\hline \multirow{2}{*}{ Explanatory variables } & \multicolumn{2}{|c|}{ Addition of minimum wage lag effect } & \multicolumn{2}{|c|}{ Double logarithmic estimation } \\
\hline & Model 1 & Model 2 & Model 3 & Model 4 \\
\hline Minimum wage & $\begin{array}{c}-0.026 \\
(0.006)^{* * *} \\
\end{array}$ & $\begin{array}{c}-0.024 \\
(0.006)^{* * *} \\
\end{array}$ & $\begin{array}{c}-0.293 \\
(0.062) * * *\end{array}$ & $\begin{array}{c}-0.26996 \\
(0.062)^{* * *}\end{array}$ \\
\hline $\begin{array}{l}\text { The minimum wage lags } \\
\text { behind }\end{array}$ & $\begin{array}{c}-0.019 \\
(0.005)^{* * *} \\
\end{array}$ & $\begin{array}{c}-0.017 \\
(0.006) * * * \\
\end{array}$ & - & - \\
\hline GDP growth index & $\begin{array}{c}0.02 \\
(0.010)^{* *}\end{array}$ & $\begin{array}{c}0.02 \\
(0.010)^{* *}\end{array}$ & $\begin{array}{c}0.191 \\
(0.044)^{* * *}\end{array}$ & $\begin{array}{c}0.152 \\
(0.048)^{* * *}\end{array}$ \\
\hline Unemployment rate & $\begin{array}{c}0.038 \\
(-0.04)\end{array}$ & $\begin{array}{c}0.023 \\
(-0.035)\end{array}$ & $\begin{array}{c}0.243 \\
(0.054)^{* * *}\end{array}$ & $\begin{array}{c}0.215 \\
(0.052)^{* * *}\end{array}$ \\
\hline Consumer Price Index & $\begin{array}{l}0.0003 \\
(-0.006)\end{array}$ & $\begin{array}{c}0.001 \\
(-0.007) \\
\end{array}$ & $\begin{array}{c}0.093 \\
(-0.242) \\
\end{array}$ & $\begin{array}{c}0.002 \\
(0.249) \\
\end{array}$ \\
\hline Labor supply & $\begin{array}{c}2.767 \\
(1.159)^{* *} \\
\end{array}$ & $\begin{array}{c}2.715 \\
(1.201)^{* *} \\
\end{array}$ & $\begin{array}{c}0.881 \\
(0.311)^{* * *} \\
\end{array}$ & $\begin{array}{c}0.684 \\
(0.323)^{* * *}\end{array}$ \\
\hline The minimum wage dummy & - & $\begin{array}{c}0.037 \\
(-0.065) \\
\end{array}$ & - & $\begin{array}{c}0.048 \\
(0.021)^{* *} \\
\end{array}$ \\
\hline Constant term & $\begin{array}{c}5.871 \\
(1.140)^{* * *} \\
\end{array}$ & $\begin{array}{c}5.842 \\
(1.141)^{* * *} \\
\end{array}$ & $\begin{array}{c}2.109 \\
(1.281)^{*}\end{array}$ & $\begin{array}{c}2.488 \\
(1.205)^{* *} \\
\end{array}$ \\
\hline Provincial dummy variables & YES & YES & YES & YES \\
\hline Minimum wage flexibility & -0.23193 & -0.21307 & -0.293 & -0.27 \\
\hline Sample size & 300 & 300 & 330 & 330 \\
\hline
\end{tabular}

Data sources: according to China Labor Statistical Yearbook and China Statistical Yearbook

From the estimation results of robustness test of the above, we find that when considering the minimum wage on the lag effect of employment, whether we change the form of the function, or the use of double logarithmic estimates, the minimum wage has a negative impact on the employment of the conclusions are very significant.

\subsubsection{Dynamic estimation}

By adding lagged explanatory variables to the regression equation, that is, using lagged employment as an explanatory variable for dynamic estimation, we can consider that employment is slow to respond to the change of its influencing factors or is a missing variable. Since the minimum wage in various parts of China is generally adjusted every other year, it only includes the first-order lag of the explained variables when considering the lagging effect. This paper uses the differential GMM estimation method proposed by Arellano and Bond to estimate.

Table 4: Dynamic estimation of the impact of minimum wages on employment

\begin{tabular}{|c|c|c|}
\hline \multirow{2}{*}{ Explanatory variables } & Model 1 & Model 2 \\
\cline { 2 - 3 } $\begin{array}{c}\text { Informal employment lags behind a } \\
\text { period of employment }\end{array}$ & Differential GMM estimation & Differential GMM estimation \\
\hline Minimum wage & 0.154 & 0.147 \\
$(0.014)^{* * *}$ & $-0.012)^{* * *}$ \\
\hline GDP growth index & -0.013 & $(0.004)^{* * *}$ \\
\hline Unemployment rate & $(0.005)^{* * *}$ & 0.02 \\
& 0.022 & $(0.009)^{* *}$ \\
\hline Consumer Price Index & $(0.008)^{* * *}$ & 0.238 \\
& 0.219 & $(0.080)^{* * *}$ \\
\hline Labor supply & $(0.098)^{* *}$ & 0.007 \\
& 0.009 & $(0.003)^{* *}$ \\
\hline The minimum wage dummy & $(0.003)^{* *}$ & -0.452 \\
$(-0.778)$
\end{tabular}


Table 4 continued

\begin{tabular}{|c|c|c|}
\hline Constant term & $\begin{array}{c}1.767 \\
(0.643)^{* * *}\end{array}$ & $\begin{array}{c}1.868 \\
(0.509)^{* * *}\end{array}$ \\
\hline Provincial dummy variables & $\mathrm{NO}$ & -0.10173 \\
\hline Minimum wage flexibility & -0.12544 & 0.1687 \\
\hline First-order autocorrelation test P value & 0.2908 & 0.1687 \\
\hline $\begin{array}{c}\text { Second-order autocorrelation test P } \\
\text { value }\end{array}$ & 0.1711 & 0.0903 \\
\hline $\begin{array}{c}\text { Over-recognition of tool variables } \\
\text { Test P value }\end{array}$ & 0.0919 & 270 \\
\hline Sample size & 270 & 2 \\
\hline
\end{tabular}

Data sources: according to China Labor Statistical Yearbook and China Statistical Yearbook

According to the two-step differential GMM estimation results, whether including dummy variables, the minimum wage variable and the explanatory can pass the significant test of $1 \%$ level, which shows that the model of employment has a significant lag effect, and the effect is positive, which is an line with the basic economic theory. The Arellano-Bond tests of the first and two order autocorrelation of the difference of the perturbation terms are reported respectively in the reciprocal row fifth and the fourth row in Table 4, and the two step differential GMM estimation is effective in general, and the $\mathrm{P}$ values of the two methods are generally valid.

\section{Summary}

From an empirical point of view, this paper takes the employment of informal workers in urban units most sensitive to the minimum wage as the research object. Using the panel data of 30 provinces in our country from 2000 to 2010, we use the two-step FGLS Regression analysis of the impact of minimum wage on the employment of urban residents in China.

The results show that there is a significant negative correlation between the minimum wage and the employment of non-regular workers in our country, the minimum wage increases by $10 \%$ relative to the average wage of the society, and the proportion of informal workers in urban employment drops by about $2.3 \%$. Based on the regression results of the basic model, this paper conducts a variety of sensitivity analysis, and dynamically regress the lag effect and omission variables of various factors in employment. The elasticity of the minimum wage expands to $-0.1 \sim-0.29$, All of which show that the minimum wage in our country reduces the employment of informal workers.

The comparative advantage of China in participating in international competition is that of labor-intensive industries. When adjusting the minimum wage, it has to bear the cost of losing some of the most sensitive personnel. Adjusting the minimum wage should be a step-by-step process. Therefore, on the one hand, government departments must take full account of this impact in the adjustment of the minimum wage level and the reform of the minimum wage system in our country. On the one hand, we should implement an active labor market policy and actively organize social training so as to raise the skill level of informal workers. At the same time, we should increase investment in education and health care so as to ease the employment pressure on urban residents so that urban residents can fully enjoy the policy effect of raising the minimum wage system to raise their wages.

\section{References}

[1] Cahuc, P, and A. Zylberberg, Labor Economics [M]. Cambridge University Press, 2004.

[2] Richard Burkhauser, Kenneth Couch, David Wittenburg. "A Reassessment of the New Economics of the Minimum Wage Literature with Monthly Data from the Current Population Survey" [J]. Journal of Labor Economics, vol. 18, pp. 4-10, 2000. 
[3] Yong Xie. Is China's Minimum Wage Level Really Low? - Evidence from Re-estimation of Average Social Wages [J]. Social Science Journal, vol.2, pp.52-63, 2016.

[4] Lan Lan, Xizai Jing, Shengji Li. Research of the Employment Effects of Minimum Wage System-an Analysis Based on Panel Data [J]. Taxation and Economy, vol.6, pp.23-28, 2015. 